\title{
The Development of Leadership Qualities In 6-7- Year-Old Children in The Process of Joint Activities
}

\author{
Tatiana Dmitrievna Savenkova ${ }^{1 *}$, Svetlana Ivanovna Karpova ${ }^{1}$, Elena Ivanovna Sukhova ${ }^{1}$, \\ and Nina Pavlovna Khodakova ${ }^{1}$ \\ ${ }^{1}$ Moscow City University, Institute of Pedagogy and Psychology of Education, Moscow, Russia
}

\begin{abstract}
The article presents the description of an empirical study testing the effectiveness of a program for the development of leadership qualities in 6-7-year-old children in the process of joint activities titled "Everyone can become a leader!". The structure of the program comprises three blocks: block 1 (cognitive) - "What is leadership and what a leader should be like", objectives: the formation of children's knowledge of about leadership, the qualities of a leader, the development of their creative thinking; block 2 (communicative) - "Learning to understand each other and communicate", objectives: overcoming communication barriers, the development of children's emotional sphere and communication skills; block 3 (behavioral) - "Learning to organize and manage", objectives: the formation of children's skills of organization and management of joint activities with peers. The main method of the study is a pedagogical experiment comprising the forming, the confirmatory, and the control experiment stages. The results of primary diagnostics conducted prior to the beginning of children's lessons as a part of the program indicate the lack of differences between the experimental and control groups by the level of leadership qualities development. The analysis of the results of secondary diagnostics conducted at the end of the forming experiment stage demonstrated that children's level of leadership qualities development in the experimental group exceeded the one in the control group. The authors can, therefore, conclude on the positive effect of the program on the development of leadership qualities in 6-7-year-old children and the opportunity of using the program in the educational process of preschool institutions.
\end{abstract}

\section{Introduction}

Children's leadership is viewed in scientific literature as a socio-psychological phenomenon and a preschool group is examined as the first step of social organization of people where the origins of the leadership phenomenon are found [1]. In older preschool age, leadership manifests in a child having a set of personal qualities allowing them to be an informal leader in a group of peers: to execute leading roles in games, manage children's activities, influence their behavior, etc. [2]. Aspiration for dominance presents one of the determinants of the

\footnotetext{
* Corresponding author: savenkovatd@,mgpu.ru
} 
leadership status in older preschool age, moreover, the prevalence in the desire for a certain modality of dominance is observed: either positive (goodwill, readiness to help and provide support) or negative dominance (demonstration of superiority, aggression, the desire to subjugate other children) [3, 4]. The guidance of a teacher in various types of joint activities of children allows to overcome the egocentrism characteristic of preschoolers, to help every child to manifest and develop leadership qualities and form behavior strategies oriented towards cooperation and achieving common goals [5].

The goal of the study is to develop a program for the development of leadership qualities in 6-7-year-old children in the process of joint activity with peers and empirically test its effectiveness.

The research objectives are to form a set of diagnostic methods for the study of the level of leadership qualities development in 6-7-year-old children, to identify the correlations between the parameters of leadership qualities in order to justify the correctness of their choice, and to analyze the results of the empirical study.

\section{Methods}

The empirical study was conducted in the period from September 2018, to June 2019, on the basis of preschool institutions located in Moscow, Russia. The study involved 224 children aged 6 to 7 years old (112 people in the experimental group, 112 people in the control group) and 10 teachers. The deployed methods include observation, experiment, measurement, and comparative analysis of experimental data. The empirical study composed three stages.

The first (confirmatory) stage involved studying the initial level of leadership qualities development in 6-7-year-old children; at the second (forming) stage, the program for the development of leadership qualities in 6-7-year-old children in joint activity was realized; at the third (control) stage, we conducted secondary diagnostics in the experimental and control groups in order to identify the dynamics of leadership qualities development in 7-year-old children.

Most researchers attribute initiative, communication skills, creative thinking, speech activity, flexible social behavior skills (soft skills), diligence, independence, empathy, and the ability to understand others' emotional state to the "reference set" of personal qualities of an older preschool child leader [6,7]. in identifying the level of leadership qualities development in 6-7-year-old children, we used a complex of diagnostic methods (see Table $1)$.

Table 1. Diagnostic methods for the evaluation of leadership qualities in 6-7-year-old children

\begin{tabular}{|l|l|l|}
\hline & Leadership qualities & Diagnostic method \\
\hline 1. & Creative thinking & Torrance Tests of Creative Thinking [8] \\
\hline 2. & Speech development level & Wechsler's test, "Vocabulary" subtest [9] \\
\hline 3. & Empathy & T.P. Gavrilova projective technique "Unfinished tales" [9] \\
\hline 4. & Communication skills & A method of expert evaluation by teachers [9] \\
\hline 5. & Self-esteem & E.V. Piers and D.M. Harris's method [10] \\
\hline 6. & Flexible behavior skills & Rosenzweig picture frustration method [11] \\
\hline 7. & Initiative, diligence & $\begin{array}{l}\text { Child observation method, evaluation criteria by V.G. } \\
\text { Maralov and V.A. Sitarov [12] }\end{array}$ \\
\hline 8. & Independence & $\begin{array}{l}\text { Child observation method, filling the independence } \\
\text { manifestation chart, indicators by A.M. Shchetinina [9] }\end{array}$ \\
\hline 9. & $\begin{array}{l}\text { Child's understanding of other } \\
\text { people's emotional state }\end{array}$ & "Mood alphabet" method by N.L. Belopolskaia [9] \\
\hline
\end{tabular}

The formation stage of the study conducted in the period from October 2018, to May 2019 , presented the implementation of the program for leadership qualities development in 
6-7-year-old children in joint activity. Prior to the realization of the program, we held several seminars with teachers of the experimental group they were familiarized with the program for the development of children's leadership qualities and explained their own role in it. The main role of a teacher included cooperative participation in lessons along with children, mastering the methods and techniques for managing joint activity of children with the goal of teachers being able to continue the work on the formation of leadership qualities in children in case of the experiment being successful.

The structure of the program for the development of leadership qualities on 6-7-year-old children in joint activity comprised three interconnected blocks: the cognitive block, the communicative block, and the behavioral block. The main objectives of work in each block are described in Table 2.

Table 2. The main blocks of the "Everyone can become a leader" program for the development of leadership qualities in 6-7-year-old children in joint activity

\begin{tabular}{|l|l|}
\hline Program blocks & Objectives \\
\hline $\begin{array}{l}\text { Block 1. Cognitive } \\
\text { "What is leadership and what a } \\
\text { leader should be like" }\end{array}$ & $\begin{array}{l}\text { Formation of children's knowledge about leadership and a } \\
\text { leader, about personal qualities of a true leader; formation of } \\
\text { children's knowledge about themselves, their personal qualities, } \\
\text { themselves as a part of a group; development of creative } \\
\text { thinking. }\end{array}$ \\
\hline $\begin{array}{l}\text { Block 2. Communicative } \\
\text { "Learning to understand each } \\
\text { other and communicate" }\end{array}$ & $\begin{array}{l}\text { Development of emotional sphere, speech activity; overcoming } \\
\text { communication barriers; formation of communicative skills. }\end{array}$ \\
\hline $\begin{array}{l}\text { Block 3. Behavioral } \\
\text { "Learning to organize and } \\
\text { manage" }\end{array}$ & $\begin{array}{l}\text { Formation of children's flexible behavior skills, the skills of } \\
\text { organization and management of various types of peers' joint } \\
\text { activity. }\end{array}$ \\
\hline
\end{tabular}

The objectives of the first two blocks of the program are fulfilled during special gaming lessons and the objectives of the third block were met during the various types of joint activities of children (play, work, theatrical activities, etc.). The main methods deployed in completing the tasks of the first two program blocks included conversations, creating stories, self-analysis, self-reflection, and completing creative tasks [13]. Conversations held with children were centered around the topics of the concept of "leadership", who is a true leader, and what personal qualities should they possess (activism, friendliness, independence, responsibility for the result of the work and for the members of their team, etc.). Children were prompted to write tales: about themselves ("Visiting card"), about themselves as a part of the group ("Me and my team", "Do we know how to be friends"), etc.

The TRIZ (theory of the resolution of invention-related tasks) tasks were deployed for the development of creative thinking with the goal of overcoming stereotypes of thinking, development of creative imagination, the ability to identify contradictions, find several solutions to resolve problem situations [14]. Sketches and games for the reproduction of various emotional states, the development of friendly relationships, and overcoming communication barriers were used as a part of fulfilling the objectives of the cognitive block of the program [15]. During the lessons, special emphasis was put on familiarizing children with the examples of adequate expression of their emotional state, positive or negative feelings, teaching the ways of reacting to various emotions of loved ones or peers (for example, reaction to anger, resentment, disgust), acquiring the experience of regulating their behavior in correspondence with the communicative situation, among other things, through the means of children's subculture (counting rhymes, reconciliation rhymes, answers to name-calling, etc.) [16]. The studies conducted by us on the development of social intellect in older preschoolers in the process of joint activity demonstrated that achieving success presents an important condition for the manifestation and development of leadership qualities 
in children. The third block of the program accentuates pedagogical guidance. The guidance of a pedagogue includes performing a role of an organizer and a manager for every student under the condition of them having the level of competence needed to successfully achieve the result with little support from a teacher; forming groups of children for joint activity on the basis of readiness for cooperation demonstrated by every child; creating situations where a child (an organizer and a manager) needs to independently search for and substantiate their strategy of activity, manifest decision-making ability. The experience of success increases self-confidence of a child, generates a sense of competence, contributes to the formation of their position of leadership in a group of peers.

\section{Results}

Table 3 presents the data on the levels of leadership qualities development in the children of the experimental and control groups at the confirmatory and control experiment stages.

Table 3. Data on the levels of leadership qualities development in the experimental and control groups of children at the confirmatory and control experiment stages (in \%)

\begin{tabular}{|c|c|c|c|c|}
\hline \multirow[t]{3}{*}{ Leadership qualities development level } & \multicolumn{2}{|c|}{$\begin{array}{l}\text { Confirmatory } \\
\text { experiment }\end{array}$} & \multicolumn{2}{|c|}{ Control experiment } \\
\hline & \multicolumn{4}{|c|}{ The number of children in groups } \\
\hline & $\begin{array}{l}\mathrm{CG} \\
\mathrm{N}=112\end{array}$ & $\begin{array}{l}\mathrm{EG} \\
\mathrm{N}=112\end{array}$ & $\begin{array}{l}\mathrm{CG} \\
\mathrm{N}=112\end{array}$ & $\begin{array}{l}\text { EG } \\
\mathrm{N}=112\end{array}$ \\
\hline High level & 7.1 & 7.1 & 9.0 & 19.6 \\
\hline Average level & $4 ., 1$ & 44.6 & 42.8 & 64.2 \\
\hline Low level & 51.8 & 48.3 & 48.2 & 16.2 \\
\hline
\end{tabular}

Note: $C G$-control group; $E G$ - experimental group

Data presented in Table 3 demonstrate that the development of leadership qualities was at the low and average levels in most children of both groups at the confirmatory experiment stage.

The lack of differences between the levels of leadership qualities development in the two groups of children was established using Student's t-test (see Figure 1).

Result: $t_{\text {emp }}=0$

Critical value

\begin{tabular}{|l|l|}
\hline \multicolumn{2}{|l|}{ tcr } \\
\hline $\mathrm{p} \leq 0.05$ & $\mathrm{p} \leq 0.01$ \\
\hline 2.78 & 4.6 \\
\hline
\end{tabular}

The zone of insignificance The zone of uncertainty The zone of significance

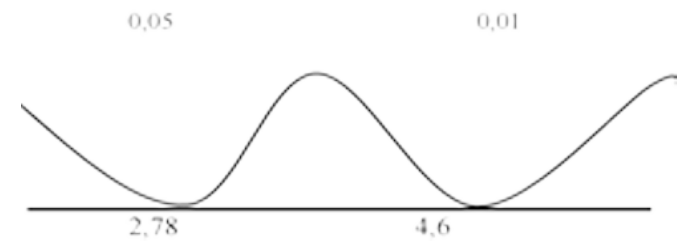

Fig. 1. Results of identifying the differences between the experimental and control groups at the confirmatory stage (Student's t-test) 
The analysis of the control experiment stage results demonstrated that in the experimental group, the number of children at the high level of leadership qualities development increased by $12.5 \%$ and the number of children at the average level increased by $19.6 \%$; in the control group, the advancement in the high level of leadership qualities development was $1.9 \%$, and the number of children at the average level increased by $1.7 \%$.

In order to identify the correlations between leadership qualities parameters, we used the Person-Brave formula. The results are presented in Table 4.

Table 4. Correlations between the parameters of leadership qualities (according to the Pearson-Brave formula)

\begin{tabular}{|l|l|l|l|l|l|l|l|l|l|l|}
\hline & 1 & 2 & 3 & 4 & 5 & 6 & 7 & 8 & 9 & 10 \\
\hline 1 & $*$ & 0.53 & 0.40 & 0.52 & 0.50 & 0.63 & 0.73 & 0.28 & 0.40 & 0.78 \\
\hline 2 & & $*$ & 0.61 & 0.54 & 0.51 & 0.64 & 0.44 & 0.17 & 0.32 & 0.70 \\
\hline 3 & & & $*$ & 0.62 & 0.56 & 0.55 & 0.46 & 0.31 & 0.28 & 0.80 \\
\hline 4 & & & & $*$ & 0.56 & 0.73 & 0.42 & 0.45 & 0.50 & 0.80 \\
\hline 5 & & & & & $*$ & 0.55 & 0.42 & 0.15 & 0.23 & 0.60 \\
\hline 6 & & & & & & $*$ & 0.82 & 0.40 & 0.46 & 0.78 \\
\hline 7 & & & & & & & $*$ & 0.26 & 0.42 & 0.71 \\
\hline 8 & & & & & & & & $*$ & 0.52 & 0.60 \\
\hline 9 & & & & & & & & & $*$ & 0.57 \\
\hline 10 & & & & & & & & & & $*$ \\
\hline
\end{tabular}

Note: 1 -communication skills, 2 - initiative and diligence, 3 -independence, 4 -flexible behavior skills, 5 - self-esteem, 6 - creative thinking, 7 - speech development, 8 - empathy, 9 - ability to understand the other person's emotional state, 10 -leadership potential.

Correlation coefficients: $0.01<\mathrm{c}<0.5$ - weak; $0.5<\mathrm{c}<0.6$ - moderate; $0.6<\mathrm{c}<0.7$ considerable; $0.7<\mathrm{c}<0.8$ - strong; $0.8<\mathrm{c}<0.9$ - close to a functional relation.

The most strong correlations were found between speech development and creative thinking $(\mathrm{r}=0.82)$, creative thinking and flexible behavior skills $(\mathrm{r}=0.73)$, speech development and communication skills $(\mathrm{r}=0.73)$, creative thinking and communication skills $(\mathrm{r}=0.63)$, initiative and diligence and creative thinking $(\mathrm{r}=0.64)$, and initiative and diligence and independence $(\mathrm{r}=0.61)$.

Moderate correlations were found between initiative and diligence and self-esteem $(\mathrm{r}=0.51)$ and communication skills $(\mathrm{r}=0,53)$, between independence and creative thinking $(\mathrm{r}=0.55)$, self-esteem and communication skills $(\mathrm{r}=0.50)$, self-esteem and independence $(\mathrm{r}=0.56)$, empathy and child's ability to understand other person's emotional state $(\mathrm{r}=0.52)$.

Therefore, the number and strength of significant correlations between leadership qualities indicate that the list of them was selected correctly, all qualities are closely interconnected and significant for a preschool child leader.

\section{Discussion}

The objective of the development of leadership qualities in children is not viewed as a priority in Russian preschool education and is not included in the list of objectives presented in the State Standard for Preschool Education. 
This situation is determined by the approaches towards the problem of child leadership formed in Russian science in the context of which this phenomenon is examined through the lens of child giftedness: special (Iu.D. Babaeva, A.M. Matiushkin, A.I. Savenkov, E.I. Shcheblanova, etc.) or general (V.Iu. Bolshakov, A.N.Ilina, D.V. Ushakov, etc.) [17].

Within these approaches, researchers develop diagnostic methods for the identification of leadership potential in children with the goal of selection for special educational programs. The conducted study demonstrated that leadership qualities developing in 6-7-year-old children and leadership development programs have great pedagogical value: children develop independence, decision-making ability, responsibility, cooperation skills, a correct idea about the qualities of a true leader, children gain the ability to withstand the negative influence of a child leader in a group.

\section{Conclusion}

The analysis of the results of the conducted study allows to make the following conclusions:

- leadership qualities in 6-7-year-old children can be developed in the conditions of the educational process of preschool institutions;

- the main conditions for the development of leadership qualities in older preschoolers comprise the inclusion of children in various types of joint activity and teacher's guidance;

- it is necessary to conduct scientific studies to identify the methods effective for the development of leadership potential in children and develop methods for the formation of leadership qualities in children at older preschool age;

- despite the wide range of scientific research on the problem of leadership, the problem remains understudied, especially regarding childhood and adolescent age. To ensure the most complete understanding of leadership, it is necessary to organize long-term studies allowing to trace the development of children who manifested leadership qualities at an early age at all the following stages of life (periods of learning and in the workplace during adulthood) [18-20].

\section{References}

1. V.M. Vugt, C.R Rueden, Leadership Quarterly 31(2), 1-9 (2020)

2. N. Klevering, R.L. McNae, Journal of Educational Leadership, Policy and Practice 33(1), 5-17 (2018)

3. D. Bailey, M. Hufford, M. Emmerson, S. Eckert, Journal of Research in Childhood Education 31(38), 487-507 (2017)

4. M. A. Cerrato, K. Thornton, M. Haggerty, Journal of educational leadership, policy and practice 33(1), 57-69 (2018)

5. T.D. Savenkova, S.I. Karpova, Bulletin of the Tambov University. Series: Humanities 24(183), 128-136 (2019).

6. E. Dietl, N. Rule, G. Blickle, Leadership Quarterly 29(4), 476-488 (2018)

7. T.Maran, M.Furtner, S. Liegl, S. Kraus, P. Sachse, Leadership Quarterly 30(6), (2019)

8. E.E. Tunik, Diagnosis of creativity. E.P. Torrance test. (Rech, Saint-Petersburg, 2000)

9. A.M. Shchetinina, Diagnosis of the social development of the child: teaching aid (NovSU named after Yaroslav the Wise, Veliky Novgorod, 2000)

10. E. Piers, D. Herzberg, Piers-Harris 2: Piers-Harris children's self-concept scale (Western Psychological Services, LosAngeles, 2002) 
11. L.I. Dementiy, Frustration: Concept and diagnosis: Textbook (Publishing House of OmSU, Omsk, 2004)

12. A.S. Sitarov, V.G. Maralov, Problems of pedagogy and psychology 4, 164-176, (2015)

13. D. A. Collyer, S. Marcovitch, Early Childhood Research Quarterly 47, 321-330 (2019)

14. Yu.G. Tamberg, How to teach a child to think (Phoenix, Rostov-on-Don, 2007)

15. M.E. Taylor, W. Boyer, Early Childhood Education Journal 48(2), 127-133 (2019)

16. I. Vinogradova, E. Ivanova, T. Savenkova, O. Tsaplina, European journal of contemporary education 6(4), 808-816 (2017)

17. A. Savenkov, S. I. Karpova, E.I. Sukhova, Psychology (Savannah, Ga.) 55(2), 74-84 (2018)

18. J. Billsberry, E.Vega, J. Molineux. Think of the children: Leader development at the edge of tomorrow. Journal of Management \& Organization 25(3) 378-381 (2019)

19. D. Karagianni, L. Montgomery, International Journal of Adolescence and Youth 23(1), 86-98 (2017)

20. T. Reitan, S.Å. Stenberg, Leadership Quarterly 30(3), 298-319 (2019) 